\title{
Hemoglobin Kansas as a Rare Cause of Cyanosis: A Case Report and Review of the Literature
}

\author{
Yoshikuni Nagayama, Minoru Yoshida, Tadashi Kohyama and Katsuyuki Matsui
}

\begin{abstract}
Hemoglobin $(\mathrm{Hb})$ Kansas is an inherited $\mathrm{Hb}$ variant with a low oxygen affinity that is associated with low oxygen saturation on pulse oximetry $\left(\mathrm{SpO}_{2}\right)$. It leads to asymptomatic cyanosis. Patients with $\mathrm{Hb}$ Kansas do not require any specific treatment and the prognosis is good. In patients with unexplained cyanosis, we should thus consider $\mathrm{Hb}$ variants, including $\mathrm{Hb}$ Kansas and avoid unnecessary investigations and managements. We herein report the case of 65-year-old woman with $\mathrm{Hb}$ Kansas and review five other cases (three lineages) that have been reported in Japan.
\end{abstract}

Key words: hemoglobin Kansas, hemoglobin variants, oxygen affinity, cyanosis

(Intern Med 56: 207-209, 2017)

(DOI: 10.2169/internalmedicine.56.7349)

\begin{abstract}
Introduction
More than $1,000 \mathrm{Hb}$ variants have been identified (1). Abnormal oxygen saturation is not detected by pulse oximetry $\left(\mathrm{SpO}_{2}\right)$ in the majority of $\mathrm{Hb}$ variants. However, some patients inherit an $\mathrm{Hb}$ variant with a low oxygen affinity that displays low $\mathrm{SpO}_{2}$ and arterial oxygen saturation $\left(\mathrm{SaO}_{2}\right)(2)$. $\mathrm{Hb}$ Kansas was first reported in 1961 as an $\mathrm{Hb}$ variant that displays a very low oxygen affinity (3). The $\mathrm{Hb}$ molecule consists of two $\beta$-globin subunits and two $\alpha$-globin subunits, which maintain the equilibrium between the relaxed state $(\mathrm{R})$, with a high oxygen affinity and the tense state (T), with a low oxygen affinity. Hb Kansas has an AAC to ACC mutation at codon 102 of the $\beta$-globin gene, which results in an asparagine (Asn) to threonine (Thr) substitution.

The binding between $\beta 102$ Asn and $\alpha 94$ Asp (aspartic acid) is imperative for the stabilization of $\mathrm{R}$; however, it is impossible for $\beta 102$ Thr to bind to $\alpha 94$ Asp. The substitution pushes the equilibrium toward $\mathrm{T}(4,5)$. Thus, patients with $\mathrm{Hb}$ Kansas present cyanosis; however, they are otherwise asymptomatic and do not require any specific treatment.
\end{abstract}

\begin{tabular}{l} 
Case Report \\
\hline A 65 -year-old woman was referred to our hospital for re- \\
nal dysfunction. She had a history of hypertension and hy- \\
percholesterolemia. Seven days prior to her admission she \\
had been diagnosed with a facial herpes zoster infection, \\
which was treated with valaciclovir and non-steroidal anti- \\
inflammatory drugs. She subsequently experienced a loss of \\
appetite. There were no remarkable symptoms with the ex- \\
ception of cyanosis of the face, lips and nail beds. Her $\mathrm{SpO}_{2}$ \\
was $70 \%$ on room air, despite the $\mathrm{SpO} \mathrm{O}_{2}$ being tested using \\
different oximeter probes on different fingers. Her complete \\
blood counts were normal (hemoglobin (Hb), $13.9 \mathrm{~g} / \mathrm{dL}$; he- \\
matocrit, $41.6 \%$; mean corpuscular volume, $89.5 \mathrm{fL}$; reticu- \\
locyte count, $1.1 \%$; white blood cell count, $5,160 / \mu \mathrm{L}$ and \\
platelet count $23.3 \times 10^{4} / \mu \mathrm{L}$ ). There was no evidence of \\
hemolysis. An arterial blood gas analysis (room air) showed \\
that the arterial partial pressure of oxygen (PaO $\mathrm{O}_{2}$ ) was 88.7 \\
$\mathrm{mmHg}$, with an $\mathrm{SaO} \mathrm{O}_{2}$ value of $58.1 \%$. Her carboxyhemoglo- \\
bin and methemoglobin levels were both negligible. A uri- \\
nalysis showed a $\mathrm{pH}$ of 5.0 , a specific gravity of 1.013 , $( \pm)$ \\
protein and $( \pm)$ blood (by dipstick), and negligible casts. \\
The urine sodium and creatinine concentrations were 21 \\
$\mathrm{mEq} / \mathrm{L}$ and $221 \mathrm{mg} / \mathrm{dL}$, respectively. Moreover, the follow- \\
ing values were observed: albumin, $4.4 \mathrm{~g} / \mathrm{dL}$; aspartate
\end{tabular}

Department of Internal Medicine IV, Teikyo University School of Medicine, University Hospital, Mizonokuchi, Japan

Received for publication March 1, 2016; Accepted for publication June 5, 2016

Correspondence to Dr. Yoshikuni Nagayama, ynaga1147@hotmail.co.jp 
Table 1. Hemoglobin Screening Tests Results of the Present Patient.

\begin{tabular}{ccc}
\hline & the present patient & normal range \\
\hline $\mathrm{HbF}(\%)$ & 0.5 & $<1.0$ \\
\hline $\mathrm{HbA}_{2}(\%)$ & 2.5 & $2 \sim 3.5$ \\
\hline Isopropanol test & $( \pm)$ & $(-)$ \\
\hline glycerol lysis time $(\mathrm{sec})$ & 32 & $22 \sim 55$ \\
\hline Inclusion body & $(-)$ & $(-)$ \\
\hline Isoelectric focusing & Abnormal band $(+)$ & $(-)$ \\
\hline
\end{tabular}

aminotransferase, $17 \mathrm{U} / \mathrm{L}$; lactate dehydrogenase, $259 \mathrm{U} / \mathrm{L}$; blood urea nitrogen, $39 \mathrm{mg} / \mathrm{dL}$; creatinine, $3.0 \mathrm{mg} / \mathrm{dL}$; uric acid, $8.6 \mathrm{mg} / \mathrm{dL}$; creatine kinase, $137 \mathrm{U} / \mathrm{L}$; sodium, 140 $\mathrm{mEq} / \mathrm{L}$; potassium, $4.3 \mathrm{mEq} / \mathrm{L}$; glucose, $128 \mathrm{mg} / \mathrm{dL}$ and Creactive protein, $0.5 \mathrm{mg} / \mathrm{dL}$. Computed tomography revealed normal kidney conformation, no pneumonia and no pulmonary edema. Sufficient fluid replacement rapidly improved her renal function, with her serum creatinine level reaching $0.74 \mathrm{mg} / \mathrm{dL}$; after which the patient recovered. Her renal dysfunction was mainly caused by pre-renal factors.

However, her $\mathrm{SpO}_{2}$ value remained low. We investigated the cause of the unexpectedly low $\mathrm{SpO}_{2}$. Ultrasound cardiography showed almost normal findings and no shunt flow. A respiratory functional test was also normal. We examined whether her $\mathrm{SpO}_{2}$ value improved when oxygen was administered in abundance. However, her $\mathrm{SpO}_{2}$ value remained at $78 \%$ under both 5 and $10 \mathrm{~L}$ oxygen by mask. On the other hand, under $5 \mathrm{~L}$ oxygen, her $\mathrm{PaO}_{2}$ and $\mathrm{SaO}_{2}$ values were $230 \mathrm{mmHg}$ and $77.4 \%$, respectively. Thus, we suspected that the patient's condition involved an $\mathrm{Hb}$ variant with low oxygen affinity. In fact, the patient had looked pale since adolescence; however, she had no critical symptoms. In addition, the patient's mother also had asymptomatic cyanosis, but she had already died. The patient's son did not have cyanosis. The $\mathrm{Hb}$ screening test results were as follows (Table 1): both the percentage of $\mathrm{HbF}$ and $\mathrm{HbA} 2$ were normal; an isopropanol test, which shows the presence of unstable $\mathrm{Hb}$, was within the normal range; the glycerol lysis time was normal and an $\mathrm{HbH}$ inclusion body test was negative (ruling out thalassemia); $\mathrm{Hb}$ electrophoresis (isoelectric focusing) revealed an abnormal band, at the approximate position of $\mathrm{HbA}$ (Figure A). Finally, a DNA sequence analysis of the $\alpha$ - and $\beta$-globin genes revealed an AAC to ACC mutation at codon 102 of the $\beta$-globin gene, resulting in asparagine to threonine substitution (Hb Kansas) (Figure B).

\section{Discussion}

Generally, patients with low $\mathrm{SpO}_{2}$ and cyanosis may suffer from some cardiopulmonary problems. However, $\mathrm{Hb}$ variants with a low oxygen affinity should be considered in patients with unexplained cyanosis, if there is dissociation between $\mathrm{PaO}_{2}$ and $\mathrm{SaO}_{2}$ (or $\mathrm{SpO}_{2}$ ). These $\mathrm{Hb}$ variants, in which the alteration of the globin structure due to a genetic mutation causes the low oxygen affinity of $\mathrm{Hb}$, are very rare. An increase in the ratio of deoxidized $\mathrm{Hb}$ to oxidized

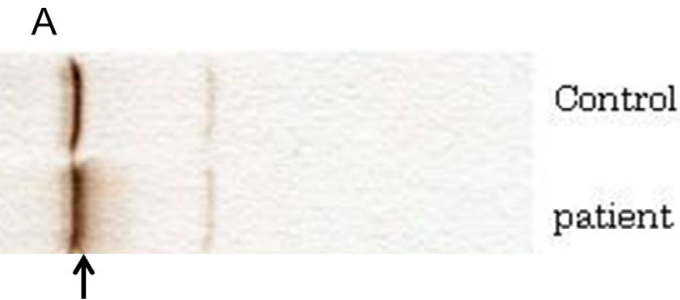

B
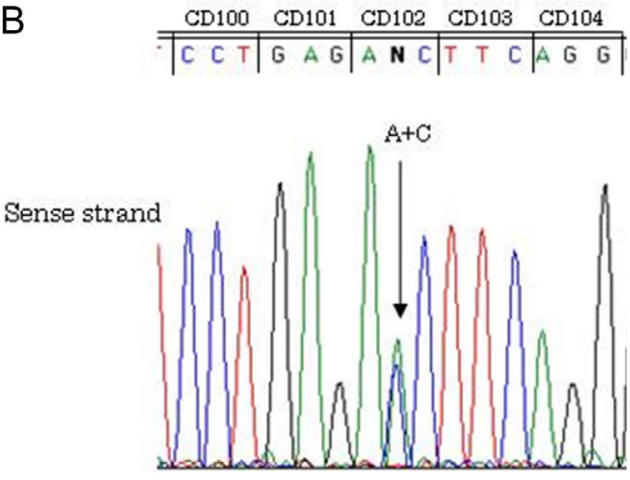

Figure. A: Hb electrophoresis (isoelectric focusing) of the patient and a control. An abnormal band around the position of HbA was observed in the patient (arrow). B: The direct DNA sequence analysis of the patient's $\beta$-globin gene. An AAC to ACC mutation was observed at codon 102 of the $\beta$-globin gene. This resulted in an asparagine to threonine substitution.

$\mathrm{Hb}$ can lead to cyanosis. Such patients are otherwise asymptomatic and display slightly decreased $\mathrm{Hb}$ levels. The oxygen dissociation curve of these patients is shifted markedly to the right in comparison to healthy controls. The delivery of oxygen to peripheral tissues may be enhanced, resulting in the reduction of erythropoietin-mediated erythropoiesis. In addition to $\mathrm{Hb}$ Kansas, $\mathrm{Hb}$ Beth Israel (6) and $\mathrm{Hb}$ Saint Mande (7) are typical $\mathrm{Hb}$ variants which display a reduced oxygen affinity, and which lead to cyanosis.

Since Ishiguro et al. reported the first case of $\mathrm{Hb}$ Kansas in a Japanese family (8), six cases (four lineages), including the case of the present patient, have been reported in Japan (8-10) (Table 2). Case nos. 1-2 and 3-5 (Table 2) were reported from Toyama (mid-west Japan) and Hokkaido (north of Japan) prefecture, respectively. Our patient was from Hokkaido; thus, there were three lineages of $\mathrm{Hb}$ Kansas in Hokkaido. However, the relationships among the families were unclear. The patients were diagnosed at various ages (9 to 65 years of age). All of the patients were diagnosed with $\mathrm{Hb}$ Kansas based on investigations for asymptomatic cyanosis and family examinations. $\mathrm{Hb}$ Kansas patients do not require any specific treatments and their prognosis is good; however patient No. 3 (Table 2) who had polycythemia and diabetes mellitus died due to a cerebral infarction.

The awareness of $\mathrm{Hb}$ variants will help ensure a timely diagnosis and avoid unnecessary investigations and managements. 
Table 2. Clinical Data of Hb Kansas Patients Reported in Japan.

\begin{tabular}{|c|c|c|c|c|c|c|c|c|c|c|}
\hline Patient No. & Ref. & Sex & $\begin{array}{c}\text { Age } \\
\text { (year) }\end{array}$ & $\begin{array}{c}\mathrm{Hb} \\
(\mathrm{g} / \mathrm{dL})\end{array}$ & $\begin{array}{c}\text { MCV } \\
\text { (fL) }\end{array}$ & $\begin{array}{c}\text { Reticulocyte } \\
(\%)\end{array}$ & $\begin{array}{l}\mathrm{SpO}_{2} \\
(\%)\end{array}$ & $\begin{array}{c}\mathrm{SaO}_{2} \\
(\%)\end{array}$ & $\begin{array}{c}\mathrm{PaO}_{2} \\
(\mathrm{mmHg})\end{array}$ & comorbidity \\
\hline 1 & 8 & $\mathrm{~F}$ & 9 & 12.4 & 80 & 2.1 & ND & 69 & 101.3 & none \\
\hline $\begin{array}{c}2 \\
\text { (father of } 1 \text { ) }\end{array}$ & 8 & M & 40 & 14.9 & 94 & 2.1 & ND & ND & 87 & none \\
\hline 3 & 9 & $\mathrm{~F}$ & 62 & 17.7 & 92 & ND & ND & 57.2 & 96.8 & Polycythemia, DM \\
\hline $\begin{array}{c}4 \\
\text { (daughter of 3) }\end{array}$ & 9 & $\mathrm{~F}$ & ND & 12.5 & 92 & ND & ND & 60.8 & 100 & ND \\
\hline 5 & 10 & $\mathrm{~F}$ & 57 & 13.7 & 96 & ND & ND & 57.3 & 84.6 & DM \\
\hline 6 & Present & $\mathrm{F}$ & 65 & 13.9 & 90 & 1.1 & 70 & 58.1 & 88.7 & Dyslipidemia, HT \\
\hline
\end{tabular}

$\mathrm{MCV}$ : mean corpuscular volume, $\mathrm{SpO}_{2}$ : oxygen saturation by pulse oximetry, $\mathrm{SaO}_{2}$ : arterial oxygen saturation, $\mathrm{PaO}$ : arterial partial pressure of oxygen, ND: not described, DM: diabetes mellitus, HT: hypertension

Note: $\mathrm{SpO}_{2}, \mathrm{SaO}_{2}$, and $\mathrm{PaO}_{2}$ were all measured under room air

The authors state that they have no Conflict of Interest (COI).

\section{Acknowledgement}

We thank Fumiya Takagi and Masafumi Kimoto (Fukuyama Medical Laboratory Co., Ltd.) for performing the $\mathrm{Hb}$ analysis.

\section{References}

1. Hardison RC, Chui DH, Giardine B, et al. HbVar: A relational database of human hemoglobin variants and thalassemia mutations at the globin gene server. Hum Mutat 19: 225-233, 2002.

2. Verhovsek M, Henderson MP, Cox G, Luo HY, Steinberg MH, Chui DH. Unexpectedly low pulse oximetry measurements associated with variant hemoglobins: A systematic review. Am J Hematol 85: 882-885, 2010.

3. Reissmann KR, Ruth WE, Nomura T. A human hemoglobin with lowered oxygen affinity and impaired heme-heme interactions. J Clin Invest 40: 1826-1833, 1961.

4. Bonaventura J, Riggs A. Hemoglobin Kansas, a human hemoglobin with a neutral amino acid substitution and an abnormal oxygen equilibrium. J Biol Chem 243: 980-991, 1968.
5. Gibson QH, Riggs A, Imamura T. Kinetic and equilibrium properties of Hemoglobin Kansas. J Biol Chem 248: 5976-5986, 1973.

6. Nagel RL, Lynfield J, Johnson J, Landau L, Bookchin RM, Harris MB. Hemoglobin Beth Israel. A mutant causing clinically apparent cyanosis. N Engl J Med 29: 125-130, 1976.

7. Arous N, Braconnier F, Thillet J, et al. Hemoglobin Saint Mande beta 102 (G4) asn replaced by tyr: a new low oxygen affinity variant. FEBS Lett 126: 114-116, 1981.

8. Ishiguro $\mathrm{K}$, Ohba $\mathrm{Y}$, Hattori $\mathrm{Y}$, et al. Hemoglobin Kansas in a Japanese family. Hemoglobin 7: 573-579, 1983.

9. Morita K, Fukuzawa J, Onodera S, et al. Hemoglobin Kansas in a patient with polycythemia. Ann Hematol 65: 229-231, 1992.

10. Ikeda $Y$, Tsutsumi $Y$, Nakata A, et al. Blood gas analysis suggested the abnormality of hemoglobin and resulted to diagnose of the unstable hemoglobin disease ( $\mathrm{Hb}$ Kansas) for a cyanosis patient. Hakodate Igaku Shi 31: 21-23, 2007 (in Japanese).

The Internal Medicine is an Open Access article distributed under the Creative Commons Attribution-NonCommercial-NoDerivatives 4.0 International License. To view the details of this license, please visit (https://creativecommons.org/licenses/ by-nc-nd/4.0/).

(C) 2017 The Japanese Society of Internal Medicine http://www.naika.or.jp/imonline/index.html 